\title{
The Current Investigation and Analysis for the Level of the Primary Schools' Football Coach in Qingdao
}

\author{
Yi Jia ${ }^{1}$ \\ ${ }^{1}$ Department of Physical Education, Qingdao University of Science and Technology, Qingdao, China \\ Correspondence: Yi Jia, Department of Physical Education, Qingdao University of Science and Technology, \\ Qingdao 266061, China. E-mail: jyqust@163.com
}

\author{
Received: March 12, $2012 \quad$ Accepted: April 9, $2012 \quad$ Published: July 1, 2012 \\ doi:10.5539/ass.v8n8p107 URL: http://dx.doi.org/10.5539/ass.v8n8p107
}

\begin{abstract}
As the leader of the football reform and the famous city in China, it's certain that Qingdao's development of the football in primary school has reprehensive. The primary school is the foundation of the basic level school and it also becomes the fertile ground which General Administration of Sport puts great effort to develop football in the school. However, the football coaches of the primary school are the executors and play a very important role in the whole system of the football events. So this thesis has invested and analyzed the current situation of the level of the primary school football coaches in Qingdao by means of questionnaires, interview and other methods. Through these ways we can find some problems that exist in the coaches. And we can put forward the appropriate measures to improve the comprehensive qualities of the football coaches in primary school and enhance the primary school in Qingdao developing smoothly.
\end{abstract}

Keywords: Qingdao city, primary school, football coach, current situation, investigation, analysis

\section{Introduction}

To chose the primary school football coaches in Qingdao as the research object, mainly because in terms of the football in china, Qingdao can be regard as the leader of the Chinese football and football here has extensive masses base. The writer wants to analyze the current situation of the level of the primary school football coaches in Qingdao to show the function and role of the football coaches in the grassroots football, and attract the attention of the Qingdao province even the General Administration of Sport. what's more, perfecting the training mechanism of the football coaches and striving to provide some models and the reference for the healthy development of the primary football in Qingdao and even our whole nation .

\section{Research Object and Research Methods}

\subsection{Research Object}

Based on the surveys and statistics, the thesis takes primary school football coaches in Qingdao city 4 districts as the research object.

\subsection{Research Methods}

\subsubsection{Interview Method for Study}

Interviewing the primary school football coaches through the way of home visiting and get the interview content directly.

\subsubsection{Questionnaire}

Distributing questionnaires to the primary school football coaches in Qingdao city 4 districts, and the number of the valid return is 52 .

\section{The Research Results and the Analysis}

\subsection{Current Natural Situation of the Coaches}

The thesis provides the research on the natural condition of the primary school football coaches in Qingdao, mainly including the current age structure, diploma structure, coaches' grade structure. 


\subsubsection{Current Situation and Analysis of the Coaches' Age Structure}

In order to know the age structure of the primary school football coaches in Qingdao, the thesis performs statistics and the result was shown in Table 1. As a whole, young and middle -aged people take a large proportion and the age of people who are above 40 only accounted for $21.15 \%$. It reflects that nowadays as the competition intensifies and the transformation of the job choosing, many young educators go to the primary school and bring vitality and new knowledge to football. However, we can't ignore that we need much more time to accumulate our knowledge. In general, experienced coaches have some advantages that the young ones don't have. According to the result of the Table 1 we can make a conclusion: the number of primary school football coaches whose age is under 30 is 25 people accounted for $48.08 \%$ of the total; Between 30 and 39 is 16 people accounted for $30.77 \%$ of the total; between 40 and 49 is 8 people accounted for $15.38 \%$; above 50 is 3 people accounted for $5.77 \%$.

Table 1. Primary school football coaches' age structure statistics

\begin{tabular}{cccccc}
\hline Index & Under 30 & $30-39$ & $40-49$ & Above 50 & total \\
\hline Number person & 25 & 16 & 8 & 3 & 52 \\
Percentage\% & 48.08 & 30.77 & 15.38 & 5.77 & 100.0 \\
\hline
\end{tabular}

\subsubsection{The Current Situation and Analysis of the Coaches' Diploma Structure}

In order to know the structure of the primary school football coaches' diploma in Qingdao, the questionnaires was conducted and the result was shown in Table 2. According to the result of the Table 2, the football coaches who have the bachelor degree in the school that invested accounted for $34.61 \%$; college degree accounted for $42.31 \%$ which is the highest proportion; secondary normal school accounted for $17.31 \%$; the percentage of the retired professional players is only $5.77 \%$. From the statistics, the record level of the coaches is rather high in primary schools in Qingdao. Compared with the football schools, the amateur sports schools and other talents training organizations which have more talents in support, the primary schools in Qingdao show more advantages. The primary school football coaches in football skills and training theories have some disadvantages over the professional players, because most of the them don't receive the specialized system training these disadvantages especially reflect that their teaching ability and demonstrated ability is limited and even several coaches can't demonstrate the basic football skills rightly. All of these affect the development of football in primary school. Among the 52 coaches surveyed, only 3 people are the retired professional players and then go to the primary school to teach football. Compared to those who have received systematic school instruction, they have some disadvantages of both diploma and teaching theories. Nevertheless, they have obvious advantages in football skill training, lead training and other aspects.

Table 2. The diploma structure of the primary school football coaches' statistics

\begin{tabular}{cccccc}
\hline Index & $\begin{array}{c}\text { Bachelor } \\
\text { degree }\end{array}$ & $\begin{array}{c}\text { College } \\
\text { degree }\end{array}$ & $\begin{array}{c}\text { Secondary normal } \\
\text { school }\end{array}$ & $\begin{array}{c}\text { Retired } \\
\text { professional } \\
\text { players }\end{array}$ & total \\
\hline Number person & 18 & 22 & 9 & 3 & 52 \\
Percentage\% & 34.61 & 42.31 & 17.31 & 5.77 & 100.0 \\
\hline
\end{tabular}

3.1.3 The Current Situation and Analysis of the Coaches' Grade Structure

China began on-the-job training of the coaches since 1987 and in 1989 the ex-National Sports Administration issued "a trial use of the coaches' on-the-job training for the notification system related issues" the notice the object and content, of on-the-job training, teaching plan the syllabus and materials, training forms and so on. The thesis performs statistics in order to know more about the grade structure of the primary school football coaches in Qingdao and the result was shown in Table 3. Through investigation and statistics we find that only 8 people have the certification of the junior football coach in all of the 52 primary school football coaches and no one has the certification of senior football coach. Other coaches don't have the certification. (See Table 3) through comprehensive analysis, we have the following reasons that cause the condition as followed: The first one is time. The football coaches need about 14 days' full-time study when they are on the position training . The leaders of the school often take the regular teaching into consideration and don't approve the teachers' leave. The second aspect is motivation. Football regards as the elective course in the primary school's teaching syllabus. The evaluations of the teachers' guidance level are not showed in the examination contents. Though the football 
teachers don't participate in the training, it's also enough for them to finish the work .So it does greatly weaken the football coaches' motivation to join in on-the-job training. The third one is expense take Class $\mathrm{C}$ as an example, if someone wants to finish the whole training, one thousand Yuan should be spent. Lacking the support of the leaders and self motivation, the primary school football coaches don't want to bear all the training costs alone. Fourth, the application is limited. The number of Local football association that holds the training classes is not enough, and the application is limited. Local football association generally gives the training opportunity to the leading coach, so the primary school PE teacher can't get the opportunity to participate in the training.

Table 3. Primary school football coaches' grade structure statistics

\begin{tabular}{cccccc}
\hline Index & Senior & Intermediate & Junior & No grade level & total \\
\hline Number person & 0 & 0 & 8 & 44 & 52 \\
Percentage $\%$ & 0.0 & 0.0 & 15.38 & 84.62 & 100.0 \\
\hline
\end{tabular}

\subsection{Structure of Coaches' Knowledge That They Want to Improve}

In order to know the structure of the primary school football coaches' knowledge they want to improve in Qingdao, the questionnaires was conducted and the result was shown in Table 4. From the Table 4 we can see that many coaches think that the specific football theories which should be improved most accounted for $94.23 \%$. This fully shows the football coaches' low level of the theories and they are in the period of emotional teaching. But this make the job of the teenager football training lose the theory guidance. Next is the training theory accounted for $80.77 \%$, we can see that the coaches in today primary school don't know much about the training theory and they are eager to learn the knowledge about this so that they can improve their capacity of training and the training methods. Half of the coaches think that their Physiological and biochemical and sports medicinal theories need to be improved. These two theories involve sport science and the coaches can learn something that related to the football so that they can arrange training scientifically, recovery, avoid sports injuries and so on. $38.46 \%$ of the coaches chose the sports psychology theory. Although the proportion is not high, it's fortunate that many coaches realized the importance of the sports psychology in the guidance of the training. Through learning the sports psychology and combining students' psychological characteristics, the coaches can grasp the students' interests easily and arrange the teaching contents properly to improve student's football skills.

Table 4. Primary school football coaches want to improve knowledge structure statistics ( $\mathrm{N}=52)$

\begin{tabular}{cccccc}
\hline Index & $\begin{array}{c}\text { Specific } \\
\text { football } \\
\text { theories }\end{array}$ & Training theory & $\begin{array}{c}\text { Sports medical } \\
\text { theory }\end{array}$ & $\begin{array}{c}\text { Physiological } \\
\text { and biochemical } \\
\text { theory }\end{array}$ & $\begin{array}{c}\text { Sports } \\
\text { psychology } \\
\text { theory }\end{array}$ \\
\hline Number person & 49 & 42 & 26 & 28 & 20 \\
Percentage\% & 94.23 & 80.77 & 50.0 & 53.85 & 38.46 \\
\hline
\end{tabular}

\subsection{Coaches' Abilities They Want to Improve}

In order to know the structure of the primary school football coaches' abilities they want to improve in Qingdao, the questionnaires was conducted and the result was shown in Table 5. According to the survey, the primary school football coaches should improve their abilities in four aspects, namely the ability of enriching the football teaching contents, making plans and organize training, managing sports injuries, football scientific research. $80.77 \%$ of the coaches in the primary school say that if the football teaching contents are boring, too formal, lack of innovation and the coaches often copy the books and they use the boring and old teaching methods, gradually all of these will influence the study enthusiasm of the students. Moreover, the ability of making plans and organizing the training are also should be improved. Through investigation, $71.15 \%$ of the coaches say that there are so many problems when making training plans, for example, not specific, too simple, ambiguous training theme, the training methods with no pertinences and lack science, poor training organization etc. $71.15 \%$ of the coaches think that they should learn more about how to managing sports injuries. Most of the methods they know are from the Sports Physiology and Sports Hygiene classes when they were at school and the contents were not taught systematically and deeply. Although the possibility of the great injury and sudden injury is low in primary school, it's their duty to take the responsibility to help the people who are injured .Only by learning more knowledge about the way of managing injury in the daily life, can the coaches deal with the situations calmly. $82.69 \%$ of the coaches realized the deficiency of the football scientific research. On the one hand, it's mainly because we can't update and accumulate knowledge quickly .On the other hand, owing to the weak 
requirement of the school leader.

Table 5. Primary school coaches want to improve abilities structure statistics $(\mathrm{N}=52)$

\begin{tabular}{ccccc}
\hline Index & $\begin{array}{c}\text { Enrich the football } \\
\text { teaching contents }\end{array}$ & $\begin{array}{c}\text { Make plans and } \\
\text { organize training }\end{array}$ & $\begin{array}{c}\text { Manage sports } \\
\text { injuries }\end{array}$ & $\begin{array}{c}\text { Football scientific } \\
\text { research }\end{array}$ \\
\hline Number person & 42 & 37 & 37 & 43 \\
Percentage \% & 80.77 & 71.15 & 71.15 & 82.69 \\
\hline
\end{tabular}

\section{Conclusion and Suggestion}

\subsection{Conclusion}

1) The age structure of the primary school football coaches in Qingdao is rather reasonable. It's helpful to the long-term development of football in primary school in Qingdao.

2) There are some disadvantages of the football teachers who are from the normal school in professional skills and training, relative to the professional coaches.

3) The grade structure of Primary school football coaches is unreasonable and the primary school football coaches in Qingdao who have the certification of grade is very little at present.

4) Primary school football coaches in Qingdao are short of both knowledge structure and capacity structure.

\subsection{Suggestion}

1) Coaches should use the advantages of their age and treasure time. They should try hard to promote comprehensive qualities and use specific methods to enrich their own teaching experience.

2) Coaches should improve the football skill of their own and participate in on-the-job training to enrich the training methods. Also, to learn some relevant theories to have more experience of leading a team.

3) We should through the effort of our own, the school leaders, municipal ministry of education and sports department and football association to increase the percentage of the primary school football coaches' level certification and thereby to improve the quality of the primary football coach.

4) Coaches should learn more specialized knowledge in their daily life. Using the theories to guide the practice to enrich the methods of teaching and training and accumulate the scientific experience on football training.

\section{References}

Chen, Chunzheng. (1995). Investigation and Analysis on the current situation of the 16 children football clubs. Journal of Shandong Sport University, 11(4), 63-65.

Ma, Zhongchen, He, Zhilin, \& Ma, Jian. (2004). Thoughts about some questions of football coaches in China. Sports Science Research, 25(4), 37-39.

Zhou, Yi. (2000). The situation and the measures to develop teenagers amateur football training. Journal of Guangzhou Sport University, 20(1), 72-76. 